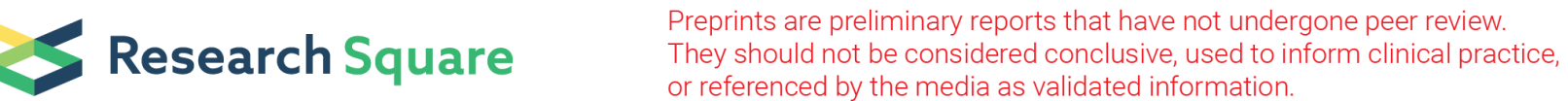

\section{Synthesis and Characterization of Epoxidized Silkworm Pupae Oil and Its Application as Polyvinyl Chloride}

\section{Yingrui Ji}

South China University of Technology

\section{Long Xu}

Henan Agricultural University

Qingqing Xu

South China University of Technology

Xuan Liu

South China University of Technology

Sen Lin

South China University of Technology

\section{Sentai Liao}

Guangdong Academy of Agricultural Sciences

weifei Wang ( $\nabla$ wangweifei@gdaas.cn )

Guangdong Academy of Agricultural Sciences https://orcid.org/0000-0001-7535-5146

\section{Dongming Lan}

South China University of Technology

\section{Research Article}

Keywords: chemo-enzymatic, epoxidation, silkworm pupae oil, plasticizing effect, packaging films

Posted Date: August 18th, 2021

DOI: https://doi.org/10.21203/rs.3.rs-756771/v1

License: (c) (1) This work is licensed under a Creative Commons Attribution 4.0 International License.

Read Full License

Version of Record: A version of this preprint was published at Applied Biochemistry and Biotechnology on October 22nd, 2021. See the published version at https://doi.org/10.1007/s12010-021-03715-5. 


\section{Abstract}

This study aimed to prepare epoxidized silkworm pupae oil (ESPO) and investigate their effects on the thermal stability and plasticization of polyvinyl chloride (PVC) films. A chemo-enzymatic method of ESPO was developed in the presence of Lipase SMG1-F278N and $\mathrm{H}_{2} \mathrm{O}_{2}$ in natural deep eutectic solvents (DESs). Lipase SMG1-F278N could initiate the epoxidation reaction effectively at room temperature with a negligible loss of activities 10 batches. A maximum oxirane value of $6.94 \%$ was obtained. The formation of oxirane ring in ESPO was confirmed by FT-IR and ${ }^{13} \mathrm{C}$ NMR spectra. Moreover, ESPO showed a better thermal stability and lower freezing point than epoxidized soybean oil (ESO). It was demonstrated that ESPO had a good frost resistance. In addition, ESPO showed a significantly improved plasticizing effect on flexible polyvinyl chloride (PVC). Compared with ESO, ESPO could increase the tensile elongation at break effectively. A significantly lower migration rate of plasticizer was observed in PVC plasticized with ESPO.

\section{Introduction}

In recent decades, epoxidation has been receiving increasing attentions in oil industries as the epoxidized fats and oils could be endowed with desirable toughness used in plasticizers [1]. It has been documented that the epoxidized soybean oil (ESO, 4.6 double bonds per triglyceride chain) enabled the significantly enhanced toughness of petro-based epoxies. Also, these epoxidized oils serve as promising eco-friendly reactive diluents [2]. The epoxidation of numerous oils has been intensively investigated and reported, including mahua oil, karanja oil, cottonseed oil, etc [3-5]. Today, the production of ESO has been successfully industrialized, thereby facilitating the synthesis of valuable plasticizers and polymer stabilizers [6].

It is demonstrated that epoxidized silkworm pupae oils (ESPO) and epoxidized linseed oil (ELO) had better thermal stability and lower coefficient of thermal expansion $[7,8]$. Moreover, the epoxidized fats and oils with high levels of linolenic acid exhibited better frost resistance used as plasticizers $[9,10]$.

Nevertheless, the industrialization of most epoxidized edible oils, including flaxseed oil, safflower oil and rapeseed oil, is greatly limited by high costs [1]. Silkworm pupae oil (SPO), usually extracted from the desilked silkworm pupae, serves as a promising substrate alternative. Almost 450,000 tons of silkworm pupae are reportedly harvested annually in China during the past two decades [3]. Unfortunately, however, tons of silkworm pupae are disposed as industrial wastes after the extraction of nutritional silkworm pupae protein. It is well-documented that silkworm pupae are enriched sources of lipids with a content of $\sim 30 \%$ [11]. Specifically, 70 80\% of the fatty acid species are composed of oleic acid, linoleic acid and a-linolenic acid (ALA) [12]. Similar unsaturation degrees (iodine value) of SPO with soybean oil are reported in previous studies $[13,14]$. Therefore, epoxidation serves as a promising effective way to achieve the high-value application of SPO. 
Traditional epoxidation reactions usually entail the stoichiometric use of peracids such as peracetic acid under acidic reaction conditions [15]. These routes are characterized with relatively harsh reaction conditions, low catalytic efficiency and low substrate conversion rates [16]. It is reported that the epoxidation of oils and fats using hydrolases as catalysts represents a promising solution to the above challenges [17]. Nevertheless, the enhancement of robustness of lipase is still a great concern nowadays, especially the resistance to $\mathrm{H}_{2} \mathrm{O}_{2}$. Gratifyingly, it was reported that the Lipase SMG1-F278N mutant had higher catalytic activities and better reusability than the wild type Lipase SMG1, especially for the production of propylene glycol monoester [18] and deacidification of oils and fats with high acid values [19]. And it is well-documented that deep eutectic solvents (DESs) enabled the enhanced robustness of lipase in chemoenzymatic epoxidation reactions [17].

In the present study, the chemo-enzymatic epoxidation of SPO catalyzed by Lipase SMG1-F278N was investigated. Furthermore, the thermal stability, cold resistance, mechanical properties and stability of ESPO, ESO and ELO were compared with respect to PVC plasticization.

\section{Materials And Methods}

\section{Biological and Chemical Materials}

Choline chloride and xylitol were purchased from Aladdin Chemistry Co., Ltd (Shanghai, China). All other reagents of analytical grade were directly used without any further purification. ESO and ELO were purchased from a domestic market.

Free Lipase G50 (Penicillium camemberti) was purchased from Amano Enzyme Products Company Japan (Japan). The wild-type Lipase SMG1 and Lipase SMG1-F278N were produced in our lab according to the method described previously [21]. Lipase SMG1, Lipase SMG1-F278N and Lipase G50 were immobilized onto epoxy resins of ECR 8285 following the procedures of Li et al [18]. The immobilized Lipase SMG1, Lipase SMG1-F278N and Lipase G50 were obtained by filtration and then dried in vacuum at $20^{\circ} \mathrm{C}$ for $12 \mathrm{~h}$. The recovered enzymes were stored at $4{ }^{\circ} \mathrm{C}$ until use. The esterification activity of immobilized Lipase SMG1, Lipase SMG1-F278N and Lipase G50 were 258, 328 and $423 \mathrm{U} / \mathrm{g}$, respectively.

\section{Extraction of SPO}

SPO was extracted by petroleum ether using a Soxhlet extractor. After reflux at $30^{\circ} \mathrm{C}$ for $8 \mathrm{~h}$, the solvent was distilled off in a rotary vacuum evaporator $(0.09 \mathrm{MPa})$. Then the obtained silkworm pupae extracts were dried with anhydrous sodium sulfate for $24 \mathrm{~h}$ [21].

\section{Preparation of DESs}

The DESs consisting of Choline chloride (ChCl, recrystallized from ethanol, filtered, and dried in vacuum) and $x y$ litol $(1: 1, \mathrm{~mol} / \mathrm{mol})$ were mixed and heated at $80^{\circ} \mathrm{C}$ in a rotary evaporator for $1 \mathrm{~h}$. The formed 
colorless, homogeneous liquids were transferred into a tightly sealed bottle, then placed in a desiccator for further use.

\section{General Procedures for Epoxidation of SPO}

Firstly, SPO $(4.3 \mathrm{~g})$ and DESs $(4.6 \mathrm{~g})$ were added to a conical flask. The mixture was supplemented with $4.6 \mathrm{~g}$ of hydrogen peroxide $\left(\mathrm{H}_{2} \mathrm{O}_{2}\right.$ : double bonds $\left.=2: 1, \mathrm{~mol} / \mathrm{mol}\right)$. The epoxidation reaction was initiated by addition of enzymes $(20 \mathrm{U} / \mathrm{g}$ oil). The reaction medium was mixed for $12 \mathrm{~h}$ at $400 \mathrm{rpm}$. The products were collected at a fixed interval ( $2 \mathrm{~h}$ ) and centrifuged for $3 \mathrm{~min}$ at $10000 \mathrm{rpm}$. The excess $\mathrm{H}_{2} \mathrm{O}_{2}$ was removed by $d_{d d H_{2}} \mathrm{O}$. The immobilized enzymes were recycled after being rinsed with excess $\mathrm{ddH}_{2} \mathrm{O}$ and dried in vacuum at $20^{\circ} \mathrm{C}$.

\section{A Scale-up Reaction}

A scale-up reaction ( 100-fold) was carried out under the optimized conditions. $108 \mathrm{~g}$ of SPO, $115 \mathrm{~g}$ of DESs and $115 \mathrm{~g}$ of hydrogen peroxide $\left(\mathrm{H}_{2} \mathrm{O}_{2}\right.$ : double bonds $\left.=2: 1, \mathrm{~mol} / \mathrm{mol}\right)$ were added to the reaction vessel. After the addition of Lipase SMG1-F278N (20 U/g oil), the epoxidation reaction was catalyzed at $30{ }^{\circ} \mathrm{C}$ for $8 \mathrm{~h}$.

\section{Analysis of Fatty Acid Composition by Gas Chromatography}

The fatty acid composition was determined as fatty acid methyl esters (FAMEs) according to the standard method described in ISO 5509:2000 (E). The FAMEs were analyzed by gas chromatographyflame ionization detector (GC-FID) equipped with a CP-Sil 88 capillary column $(60 \mathrm{~m} \times 0.25 \mathrm{~mm}, 0.2 \mu \mathrm{m}$ film thickness; Dikma Technologies, Beijing, China) [22].

\section{Determination of Physicochemical Indices}

The iodine value, oxirane value, acid value, density and moisture of the products were determined by titration according to the American Oil Chemists' Society (AOCS) Official Methods Tg 1a-64, Cd 9-57, Cd 3d-63, Cc 10c-95 and Ac 2-41, respectively.

\section{Characteristics of ESPO}

The formation of oxirane ring in ESPO was confirmed by fourier transform infrared spectrometer (FT-IR) and carbon-13 nuclear magnetic resonance $\left({ }^{13} \mathrm{C}\right.$ NMR) spectra. The FT-IR spectra of the products were recorded on an FT-IR (Thermo Scientific, model Nicolet 6700 , Waltham, MA, USA) with a resolution of 4 $\mathrm{cm}^{-1}$. Data were acquired using the FT-IR software (Thermo Scientific, OMNIC series suite, Waltham). The ${ }^{1} \mathrm{H}$ and ${ }^{13} \mathrm{C}$ NMR spectra of SPO and the derivatives $\left(10 \sim 15 \mathrm{mg} / \mathrm{mL}\right.$ in $\left.\mathrm{CDCl}_{3}\right)$ were recorded by a 600 $\mathrm{MHz}$ Brucker NMR spectrophotometer.

The thermal degradation of the obtained polymers was determined by thermogravimetric analysis (TGA) using Mettler-Toledo TGA/SDTA 851e. TG analysis was performed using a thermal weightlessness 
analyzer (TG209-F3, NETZSCH Co., Germany) in the temperature range of $25-700{ }^{\circ} \mathrm{C}$ with a rate of 10 ${ }^{\circ} \mathrm{C} / \mathrm{min}$ under $\mathrm{N}_{2}(20 \mathrm{~mL} / \mathrm{min})$.

The curing behaviors of epoxidized oils were characterized by a differential scanning calorimeter (DSC) (Netzsch Geratebau, model $204 \mathrm{C}$, Germany), in the temperature range of $-60-80^{\circ} \mathrm{C}$ with a rate of 10 ${ }^{\circ} \mathrm{C} /$ min under $\mathrm{N}_{2}$.

\section{The Mechanical Properties of PVC Samples}

In the study, the tensile strength and elongation at break of PVC films made of ESPO were investigated to evaluate the comprehensive performance of various epoxy greases according to the American Society for Testing and Materials (ASTM) standards (ASTM D638).

\section{The Thermal Stability and Migration Tests of The PVC Samples}

The plastisol was prepared by mixing $50,60,70,80,90$, and 100 phr of plasticizer with 100 phr PVC for $15 \mathrm{~min}$, respectively. Subsequently, the mixture was compounded by double-roller blending rolls (SK-160B, Shanghai Rubber Machinery Factory) at $165^{\circ} \mathrm{C}$ for $8 \mathrm{~min}$. The sample was pressed on a flat plate vulcanizing machine (HY-100TA, Shanghai Hengyu Instrument Co., Ltd.) at $170{ }^{\circ} \mathrm{C}$ for 6 min to make film with a thickness of $5 \mathrm{~mm}$. The final film was obtained after the temperature of the flat-plate vulcanizing machine dropped to $50{ }^{\circ} \mathrm{C}$.

The thermal stability of PVC samples was tested according to the Congo red method in GB/T 2917.12002. PVC samples were cut into $2 \mathrm{~mm} \times 2 \mathrm{~mm}$ and placed in test tubes. Then the test tubes were incubated in an oil bath at $170{ }^{\circ} \mathrm{C}$. The time required for color changes of the Congo red test paper represented the thermal stability.

The migration tests were performed according to the following procedures. Firstly, all samples were immersed in $n$-hexane at $50{ }^{\circ} \mathrm{C}$ for $2 \mathrm{~h}$. The weight loss was measured gravimetrically. It is considered that the weight of residue extracts present in $n$-hexane is equal to the plasticizer extracted [8].

Secondly, the mass loss of a plastic piece placed between two absorbent films was measured according to ISO 177 . Samples were placed on two plates ( $3 \mathrm{~mm}$ thick) of low density polyethylene (LDPE) at $70{ }^{\circ} \mathrm{C}$ for $24 \mathrm{~h}$ with a circular cylinder (1 $\mathrm{mm}$ thick) of PVC plasticized with ESPO in between. The amount of plasticizer migrated was determined according to the weight differences before and after tests [8].

The third migration test was conducted using activated carbon as per ASTM D 1203-94 test method B. A wire cage was used to prevent from direct contact between the plasticized PVC and carbon. The migrated volatile components were measured after the circular cylinder was placed at $100{ }^{\circ} \mathrm{C}$ for $24 \mathrm{~h}$.

\section{Statistical Analysis}


All experiments were performed in triplicate. The data were presented as mean values \pm standard deviations.

\section{Results And Discussion}

\section{Fatty Acid Composition of SPO}

The fatty acid composition of SPO is presented in Table 1. ALA was the most abundant fatty acid, accounting for almost $36 \%$ of the total fatty acid composition. The total concentration of unsaturated fatty acids was $75.13 \%$, and the iodine value of SPO was 138.7 . It was observed that the iodine value of SPO reported herein was consistent with that of soybean oil. Moreover, it was demonstrated that ALA was the primary unsaturated fatty acid. Therefore, SPO has great potentials as an alternative of soybean oil for producing epoxidized products, especially epoxidized ALA type grease in PVC.

\section{Synthesis of ESPO}

The superiority of partial glyceride lipase as a catalyst for triglyceride epoxidation has been proved in previous studies [17]. Some side reactions such as hydrolysis could be prevented effectively using partial glyceride lipase. In this study, a mutant of Lipase SMG1 (SMG1-F278N) was selected due to its higher activities and better tolerance to polar solvents [19]. Compared with commercial Lipase G50 and wild-type Lipase SMG1, Lipase SMG1-F278N exhibited higher SPO epoxidation activities (Figure 1). The epoxidation reaction reached to the equilibrium in less time using Lipase SMG1-F278N, with a higher final oxirane value (>6.9) being observed [23]. Therefore, Lipase SMG1-F278N has superior catalytic activities for epoxidation of animal and vegetable oils.

The previous studies demonstrated that the immobilized SMG1-F278N had a higher temperature tolerance, with the maximal catalytic activities at $30-35^{\circ} \mathrm{C}[18,24]$. An increasing reaction rate was observed from $20^{\circ} \mathrm{C}$ to $30^{\circ} \mathrm{C}$ (Figure 1A). However, further increment could not be found after $6 \mathrm{~h}$ when the temperature increased to $35{ }^{\circ} \mathrm{C}$. It was reported that the increased temperature and peroxyacid produced both could lead to decreased activities of immobilized lipases $[15,16]$. In our study, the low concentration (0-0.5 mol/L) of peroxyacid would not result in a significant loss of enzyme activity. Overall, it could be concluded that high temperatures $\left(>35^{\circ} \mathrm{C}\right)$ was the main factor leading to the loss of enzyme activities.

\section{Scale-up Reaction and Reusability of Immobilized SMG1-F278N}

It is generally acknowledged that immobilized lipases could be recycled easily and reused compared with free counterparts. However, the recovery of partial glyceride lipases used for triglyceride epoxidation has not been investigated. In the present study, we explored the reusability of immobilized SMG1-F278N at low temperatures $\left(25^{\circ} \mathrm{C}\right.$ and $\left.30^{\circ} \mathrm{C}\right)$ and the scale-up reactions. The results are shown in Figure 2 .

After being reused for 10 consecutive batches at $25^{\circ} \mathrm{C}$ and $30{ }^{\circ} \mathrm{C}$, the immobilized SMG1-F278N still had $94 \%$ and $96 \%$ of the original catalytic activities, with oxirane values 6.49 and 6.67 being observed. It was 
documented that Novozyme 435 retained only $73 \%$ of initial activities after being recycled once at $25{ }^{\circ} \mathrm{C}$. The enzyme could not be reused any more due to a significantly decreased activity at $>25^{\circ} \mathrm{C}$ [25]. The small amount of peroxyacid $(<0.24 \%, w / w \%)$ produced in the reaction generally could not lead to enzyme inactivation. The exogenous acids (acetic acid or other acids) added largely inhibited the hydrolysis of oils and fats. Meanwhile, these acids served as effective substrates for production of peroxyacid. However, these exogenous acids could not only lead to decreased stabilities of lipase, but increased the complexity of product separation and purification [26]. This study found that Lipase SMG1-F278N could catalyze the epoxidation of unsaturated fatty acids of SPO effectively without exogenous acids. In addition, the epoxidation reaction reported herein, to a large extent, avoided the hydrolysis of glycerides and improved the enzyme stability. The enzyme could be reused for at least 8 times without significant loss of activities.

The changes of oxirane values of ESPO products are illustrated in Figure 2B. It was found that the scaleup (by 25 times) reaction reached the equilibrium after $6 \mathrm{~h}$ with an oxirane value of $6.94 \%$. Overall, this epoxidation reaction could be scaled up with a good reproducibility.

\section{Characterization of ESPO}

The physicochemical indices of ESPO were determined. The results are shown in Table 2. Obviously, the acid value, iodine value and heating loss of ESPO were lower than that of ESO and ELO, while the content of epoxy groups of ESPO was higher than ESO. Similar densities were observed between ESO and ELO. These physicochemical parameters indicated that ESPO could serve as a promising alternative of ESO as plastic stabilizers and plasticizers [8, 27]. The acid value of ESPO increased from $0.14 \mathrm{mg} / \mathrm{g} \mathrm{KOH}$ to 0.47 $\mathrm{mg} / \mathrm{g} \mathrm{KOH}$ after epoxidation. This increment could be explained by the increased levels of free fatty acids produced via hydrolysis of diglycerides. The acid value of ESPO was less than $0.5 \mathrm{mg} / \mathrm{g} \mathrm{KOH}$, indicating that the triglycerides were not hydrolyzed.

\section{FT-IR and NMR Analysis}

The FTIR spectra of SPO and ESPO are shown in Figure 3. The absorption band at $3009 \mathrm{~cm}^{-1}$ was characteristic of $=\mathrm{C}-\mathrm{H}$ (Figure $3 \mathrm{~A}$ ). The ESPO exhibited an absorption peak at $837 \mathrm{~cm}^{-1}$ (Figure 3B), which was attributed to the epoxy group. Moreover, the peak intensity at $3009 \mathrm{~cm}^{-1}$ decreased significantly, while the peak intensity at $837 \mathrm{~cm}^{-1}$ increased dramatically with increased epoxidation degrees. Therefore, SPO was successfully epoxidized by Lipase SMG1-F278N.

Figure 4 shows the ${ }^{13} \mathrm{C}$ NMR spectrum of the SPO and ESPO. The peaks at $\delta 172.5-173.5 \mathrm{ppm}$ of SPO and ESPO were attributed to the ester carbonyls in triglycerides. The characteristic peak of $\mathrm{CH}=\mathrm{CH}$ was observed at $\delta 127.1 \mathrm{ppm}$. Obviously, a new peak at $\delta 31.5 \mathrm{ppm}$ corresponding to the epoxy group was found in the epoxide product. Therefore, it was concluded that the groups were epoxidized by Lipase SMG1-F278N effectively.

\section{Thermal Characterization}


It is generally acknowledged that the thermo resistance of epoxy grease per se could contribute to the thermal stability of PVC and other plastic products. The thermal degradation kinetics of SPO, ESO, ELO and ESPO are shown in the Figure 5.

As can be seen from Figure $5 \mathrm{~A}$, the thermal decomposition temperature of SPO increased from $374{ }^{\circ} \mathrm{C}$ to $416.3^{\circ} \mathrm{C}$ after epoxidation, which is consistent with the epoxidized vegetable oil reported previously ${ }^{28}$. Similar thermal decomposition temperatures of ESPO $\left(416.3^{\circ} \mathrm{C}\right)$ and ELO $\left(411.5^{\circ} \mathrm{C}\right)$, could be observed from Figure $5 \mathrm{~B}$, which were higher than that of ESO $\left(402.3^{\circ} \mathrm{C}\right)$. Therefore, ESPO could improve the thermal stability of plastic products significantly.

It has been demonstrated that the frost resistance of epoxy grease is closely related to solidification temperatures [9]. In this study, DSC was used to investigate the solidification temperature of ESPO. It was found that the initial solidification temperature of ESPO was $-3{ }^{\circ} \mathrm{C}$, which was close to ELO $\left(-5^{\circ} \mathrm{C}\right)$ and lower than ESO $\left(9^{\circ} \mathrm{C}\right)$ (Figure 6). Therefore, ESPO has better frost resistance than ESO as a plasticizer.

\section{Effect of Plasticizer Addition on PVC Mechanical Properties}

Some vital processing parameters including curing formulations and mechanical characterization are usually assessed to evaluate the flexibility of PVC.

As shown in Figure 7A, the tensile elongation of ESPO on PVC was higher than that of ESO with the plasticizer content of $>60 \mathrm{phr}$. The tensile strength of PVC was significantly reduced with the plasticizer content of $>80 \mathrm{phr}$ (Figure 7B). Notably, similar mechanical properties could be found with respect to the PVC sheets plasticized with ESPO and ELO [7]. This observation could be explained by that the majorities of epoxy glycerides in ESPO and ELO were epoxy linolenic acid glycerides [10]. Therefore, ESPO has better plasticizing effects on PVC than ESO.

\section{Thermal Stability and Migration Test of PVC Samples}

The results about thermal stability and migration test of PVC samples are shown in Table 3. The results demonstrated that PVCs ( 80 phr) plasticized with ESPO and ELO showed close thermal stability times of 30 min and $29 \mathrm{~min}$, respectively, which were higher than $26 \mathrm{~min}$ of ESO. Therefore, ESPO contributed to better stabilities of PVC than ESO. The emigration tests demonstrated that the migrate rate of ESPO $(-0.83 \pm 0.02 \%)$ from PVC was significantly lower than ESO $(-1.02 \pm 0.05 \%)$. Therefore, ESPO serves as a promising alternative of ESO as the raw material for production of plasticizers.

\section{Conclusions}

In the present study, an effective chemo-enzymatic route was proposed using Lipase SMG1-F278N as catalysts for ESPO in DESs. The preliminary results showed that a high catalytic efficiency for production of ESPO was observed due to the enhanced robustness of Lipase SMG1-F278N in DESs. Compared with ESO, the ESPO reported in this contribution exhibited better thermal stability and frost resistance. In 
addition, a relatively low migration rate of plasticizer was observed in PVC plasticized with ESPO. Overall, ESPO is expected to serve as a promising alternative to ESO used for packaging films.

\section{Declarations}

\section{Authors Contributions}

Yingrui Ji: experimental activities, Conceptualization, Data curation, Supervision, Formal analysis, Validation, Writing - original draft; Long Xu: Methodology, Writing - review \& editing; Qingqing Xu: Investigation; Xuan Liu: Supervision; Sen Lin: Formal analysis; Sentai Liao: experimental activities; Weifei Wang: Resources; Dongming Lan: Funding acquisition

Ethical Approval This article does not contain any studies with human participants or animals performed by any of the authors.

Consent to Participate The authors agreed to participate in this work.

Consent for Publication The authors agreed to publish this work.

Conflict of Interest The authors declare no competing interests.

\section{Finding}

The authors acknowledge funding from the National Key R\&D Program of China (2019YFD1002403), National Science Fund for Key Program of National Natural Science Foundation of China (31930084), Distinguished Young Scholars of China (31725022), China Agriculture Research System (CARS-18ZJ0503), Science and Technology Planning Project of Guangdong Province (2019A050503002), Innovation and Entrepreneurship Team of Nanhai Talent Plan of Nanhai District, Foshan (201811070001).

\section{References}

1. Zhang, C., Garrison, T. F., Madbouly, S. A., \& Kessler, M. R. (2017). Recent advances in vegetable oilbased polymers and their composites. Prog. Polym. Sci, 71, 91-143

2. Sahoo, S. K., Khandelwal, V., \& Manik, G. (2018). Development of toughened bio-based epoxy with epoxidized linseed oil as reactive diluent and cured with bio-renewable crosslinker. Polym. Adv. Technol, 29(1), 565-574

3. Goud, V. V., Patwardhan, A. V., \& Pradhan, N. C. (2006). Studies on the epoxidation of mahua oil (Madhumica indica) by hydrogen peroxide. Bioresour. Technol, 97(12), 1365-1371

4. Joshi, S. M., Gogate, P. R., \& Kumar, S. (2018). Intensification of esterification of karanja oil for production of biodiesel using ultrasound assisted approach with optimization using response surface methodology. Chem. Eng. Process, 124, 186-198 
5. Dinda, S., Patwardhan, A. V., Goud, V. V., \& Pradhan, N. C. (2008). Epoxidation of cottonseed oil by aqueous hydrogen peroxide catalysed by liquid inorganic acids. Bioresour. Technol, 99(9), 37373744

6. Klaas, M. R., \& Warwel, S. (1999). Complete and partial epoxidation of plant oils by lipase-catalyzed perhydrolysis. Ind. Crop. Prod, 9(2), 125-132

7. Xia, Y., \& Larock, R. C. (2010). Vegetable oil-based polymeric materials: synthesis, properties, and applications.Green Chemistry. 12(11).

8. Fenollar, O., Garcia-Sanoguera, D., Sanchez-Nacher, L., Lopez, J., \& Balart, R. (2010). Effect of the epoxidized linseed oil concentration as natural plasticizer in vinyl plastisols. J. Mater. Sci, 45(16), 4406-4413

9. Fenollar, O., Sanchez-Nacher, L., Garcia-Sanoguera, D., López., J., \& Balart, R. (2009). The effect of the curing time and temperature on final properties of flexible PVC with an epoxidized fatty acid ester as natural-based plasticizer. J. Mater. Sci, 44(14), 3702-3711

10. Milchert, E., Smagowicz, A., \& Lewandowski, G. (2010). Optimization of the reaction parameters of epoxidation of rapeseed oil with peracetic acid. J. Chem. Technol. Biot, 85(8), 1099-1107

11. Wei, Z., Liao, A., Zhang, H., Liu, J., \& Jiang, S. (2009). Optimization of supercritical carbon dioxide extraction of silkworm pupal oil applying the response surface methodology. Bioresour. Technol, 100(18), 4214-4219

12. Wang, W., Xu, L., Zou, Y., Pang, D., Shi, W., Mu, L. ... Wang, Y. (2019). Comprehensive Identification of Principal Lipid Classes and Tocochromanols in Silkworm (Antheraea pernyi and Bombyx mori) Pupae Oils. Eur. J. Lipid Sci. Technol.122(2).

13. Jiang, Y. (2013). Separation of Polyunsaturated Fatty Acids from Silkworm Oil with Urea Adduction. The. Food. Ind, 34(5), 35-37

14. Allauddin, S., Somisetti, V., Ravinder, T., Rao, B., Narayan, R., \& Raju, K. (2016). One-pot synthesis and physicochemical properties of high functionality soy polyols and their polyurethane-Urea coatings. Ind. Crop. Prod, 85, 361-371

15. Orellana-Coca, C., Camocho, S., Adlercreutz, D., Mattiasson, B., \& Rajni, H-K. (2005). Chemo-enzymatic epoxidation of linoleic acid: Parameters influencing the reaction. Eur. J. Lipid Sci. Technol, 107(12), 864-870

16. Quadrosjr, J. V. D., \& Giudici, R. (2016). Epoxidation of soybean oil at maximum heat removal and single addition of all reactants. Chem. Eng. Processing, 100, 87-93

17. Zhou, P., Wang, X., Zeng, C., Wang, W., Yang, B., \& Hollmann, F. (2017). Deep Eutectic Solvents Enable More Robust Chemoenzymatic Epoxidation Reactions. ChemCatChem, 9(6), 934-936

18. Li, X., Li, D., Wang, W., Durrani, R., \& Yang, B. (2016). Immobilization of SMG1-F278N lipase onto a novel epoxy resin: Characterization and its application in synthesis of partial glycerides. J. Mol. Catal. B-Enzym, 133, 154-160

19. Li, D., Wang, W., Durrani, R., Li, X., Yang, B., \& Wang, Y. (2016). Simplified Enzymatic Upgrading of High-Acid Rice Bran Oil Using Ethanol as a Novel Acyl Acceptor. J. Agric. Food. Chem, 64(35), 6730- 
6737

20. Xu, T., Lu, L., Hou, S., Xu, J., Yang, B., \& Wang, Y. (2012). Crystal structure of a mono- and diacylglycerol lipase from Malassezia globosa reveals a novel lid conformation and insights into the substrate specificity. J. Struct. Biol, 178(3), 363-369

21. Hu, B., Li, C., Zhang, Z., Zhao, Q., Zhu, Y., \& Su, Z. (2017). Microwave-assisted extraction of silkworm pupal oil and evaluation of its fatty acid composition, physicochemical properties and antioxidant activities. Food. Chem, 231, 348-355

22. Wang, Y., Mai, Q., Qin, X., Yang, B., \& Wang, Z. (2010). Establishment of an evaluation model for human milk fat substitutes. J. Agric. Food. Chem, 58(1), 642-649

23. Wang, X., Tang, Q., Grzegorz, M. P., Yang, B., \& Wang, Y. (2015). A mechanistic study into the epoxidation of carboxylic acid and alkene in a mono, di-acylglycerol lipase. Biochem. Biophys. Res. Commun, 460(2), 392-396

24. Wang, W., Xu, Y., Qin, X., Lan, D., Yang, B., \& Wang, Y. (2014). Immobilization of lipase SMG1 and its application in synthesis of partial glycerides. Eur. J. Lipid Sci. Technol, 116(8), 1063-1069

25. Vlček, T., \& Petrović, Z. S. (2006). Optimization of the chemoenzymatic epoxidation of soybean oil. J. Am. Oil Chem. Soc, 83(3), 247-252

26. Dinda, S., Goud, V. V., Patwardhan, A. V., \& Pradhan, N. C. (2011). Selective epoxidation of natural triglycerides using acidic ion exchange resin as catalyst. Asia-Pac J Chem Eng, 6(6), 870-878

27. Eiichi, K. N., Kanako, Y., Mitsuyoshi, N., Kazuo, M., \& Tsuyoshi, M. (2002). Lipid Profiles and Oxidative Stability of Silkworm Pupal Oil. J. Oleo. Sci, 51(11), 681-690

28. Kim, J. R., \& Sharma, S. (2012). The development and comparison of bio-thermoset plastics from epoxidized plant oils. Ind. Crop. Prod, 36(1), 485-499

\section{Tables}

Table 1. Fatty acid composition of SPO 


\begin{tabular}{|llllll|}
\hline Fatty acids & Abbreviation & $\begin{array}{l}\text { Concentration } \\
(w t \%)\end{array}$ & $\begin{array}{l}\text { Ref (Eiichi et al., } \\
\text { 2002) }\end{array}$ & $\begin{array}{l}\text { Ref (Hu et al., } \\
2017)\end{array}$ & $\begin{array}{l}\text { Ref (Liu et al., } \\
2015)\end{array}$ \\
$\begin{array}{l}\text { Palmitic } \\
\text { acid }\end{array}$ & C16:0 & $19.62 \pm 0.47$ & 24.90 & $23.18 \pm 0.52$ & $19.50 \pm 0.97$ \\
$\begin{array}{l}\text { Palmitoleic } \\
\text { acid }\end{array}$ & cis-9-C16:1 & $1.39 \pm 0.12$ & 0.80 & $1.07 \pm 0.09$ & ND \\
\hline $\begin{array}{l}\text { Stearic acid } \\
\text { C18:0 }\end{array}$ & $4.73 \pm 0.51$ & 5.40 & $4.69 \pm 0.17$ & $7.05 \pm 0.35$ \\
\hline Oleic acid & cis-9-C18:1 & $29.72 \pm 0.61$ & 24.30 & $28.32 \pm 0.63$ & $31.16 \pm 1.56$ \\
\hline $\begin{array}{l}\text { Linoleic acid } \\
\text { cis-9,12- }\end{array}$ & $7.96 \pm 0.23$ & 6.30 & $3.88 \pm 0.13$ & $7.55 \pm 0.38$ \\
\hline $\begin{array}{l}\text { Linolenic } \\
\text { acid }\end{array}$ & $\begin{array}{l}\text { cis-9,12,15- } \\
\text { C18:3 }\end{array}$ & $36.07 \pm 0.64$ & 36.00 & $38.25 \pm 0.75$ & $34.73 \pm 1.74$ \\
\hline Others & & $0.51 \pm 0.03$ & 0.20 & $0.59 \pm 0.09$ & ND \\
\hline
\end{tabular}

Table 2. Physico-chemical indices of modified SPO

\begin{tabular}{|c|c|c|c|c|c|}
\hline parameters & SPO & ESPO & ESO & ELO & $\begin{array}{l}\text { Detection } \\
\text { method }\end{array}$ \\
\hline $\begin{array}{l}\text { Acid value } \\
(\mathrm{mg} \mathrm{KOH} / \mathrm{g})\end{array}$ & $\begin{array}{l}0.14 \pm \\
0.02\end{array}$ & $\begin{array}{l}0.47 \pm \\
0.05\end{array}$ & $\begin{array}{l}0.51 \pm \\
0.03\end{array}$ & $\begin{array}{l}1.02 \pm \\
0.06\end{array}$ & AOCS Cd 3d-63 \\
\hline $\begin{array}{l}\text { Iodine value } \\
\left(\mathrm{g} \mathrm{I}_{2} / 100 \mathrm{~g}\right)\end{array}$ & 138.7 & $\begin{array}{l}4.31 \pm \\
0.23\end{array}$ & $\begin{array}{l}5.01 \pm \\
0.38\end{array}$ & $\begin{array}{l}4.47 \pm \\
0.25\end{array}$ & AOCS Tg 1a-64 \\
\hline Oxirane value (\%) & 0.00 & $\begin{array}{l}6.93 \pm \\
0.37\end{array}$ & $\begin{array}{l}5.74 \pm \\
0.45\end{array}$ & $\begin{array}{l}9.01 \pm \\
0.43\end{array}$ & $\begin{array}{l}\text { AOCS Cd } \\
9-57\end{array}$ \\
\hline Water solubility & $\begin{array}{l}\text { Non } \\
\text { soluble }\end{array}$ & $\begin{array}{l}\text { Non } \\
\text { soluble }\end{array}$ & $\begin{array}{l}\text { Non } \\
\text { soluble }\end{array}$ & $\begin{array}{l}\text { Non } \\
\text { soluble }\end{array}$ & \\
\hline $\begin{array}{l}\text { Density at } 20^{\circ} \mathrm{C}\left(\mathrm{g} / \mathrm{cm}^{-}\right. \\
3)\end{array}$ & $\begin{array}{l}0.93 \pm \\
0.02\end{array}$ & $\begin{array}{l}0.99 \pm \\
0.01\end{array}$ & $\begin{array}{l}0.99 \pm \\
0.01\end{array}$ & $\begin{array}{l}1.03 \pm \\
0.02\end{array}$ & AOCS Cc 10c-95 \\
\hline $\begin{array}{l}\text { Heating loss } \\
(\%)\end{array}$ & $\begin{array}{l}0.12 \pm \\
0.01\end{array}$ & $\begin{array}{l}0.19 \pm \\
0.01\end{array}$ & $\begin{array}{l}0.21 \pm \\
0.02\end{array}$ & $\begin{array}{l}0.34 \pm \\
0.03\end{array}$ & $\begin{array}{l}\text { AOCS AC } \\
2-41\end{array}$ \\
\hline
\end{tabular}

Table 3. Thermal stability and migration test 


\begin{tabular}{|lllll|}
\hline Samples & Thermal stability time $(\mathrm{min})$ & $\begin{array}{l}n \text {-hexane } \\
(\%)\end{array}$ & $\begin{array}{l}\text { Migration } \\
(\%)\end{array}$ & Active carbon (\%) \\
\hline ESO-PVC & $26 \pm 1.6$ & $0.19 \pm 0.03$ & $-1.02 \pm 0.05$ & $0.18 \pm 0.02$ \\
\hline ELO-PVC & $29 \pm 1.9$ & $0.11 \pm 0.04$ & $-0.81 \pm 0.03$ & $0.13 \pm 0.01$ \\
\hline ESPO-PVC & $30 \pm 1.3$ & $0.12 \pm 0.02$ & $-0.83 \pm 0.02$ & $0.14 \pm 0.01$ \\
\hline
\end{tabular}

Figures
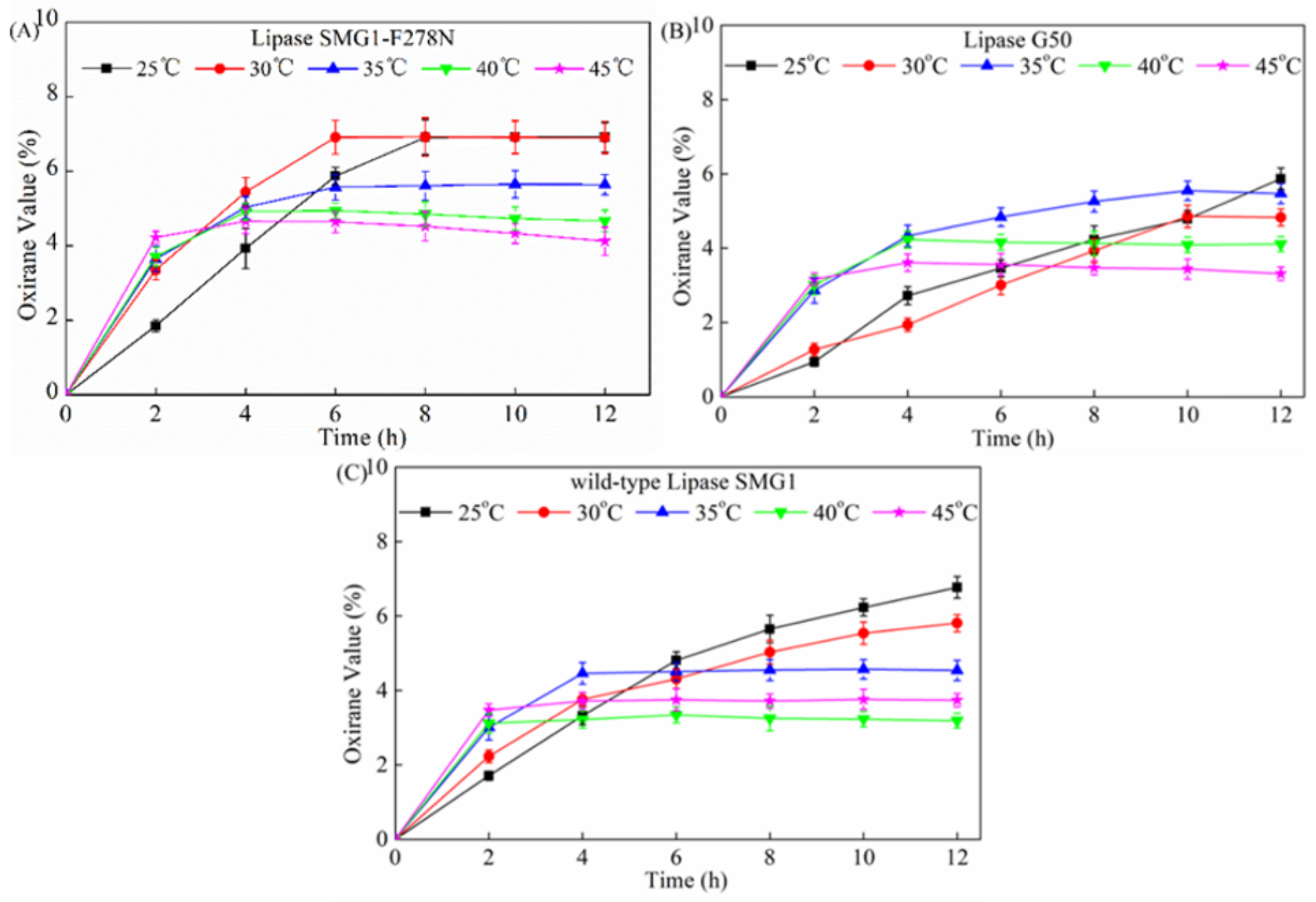

Figure 1

Effects of temperature on epoxidation activities of different enzymes 

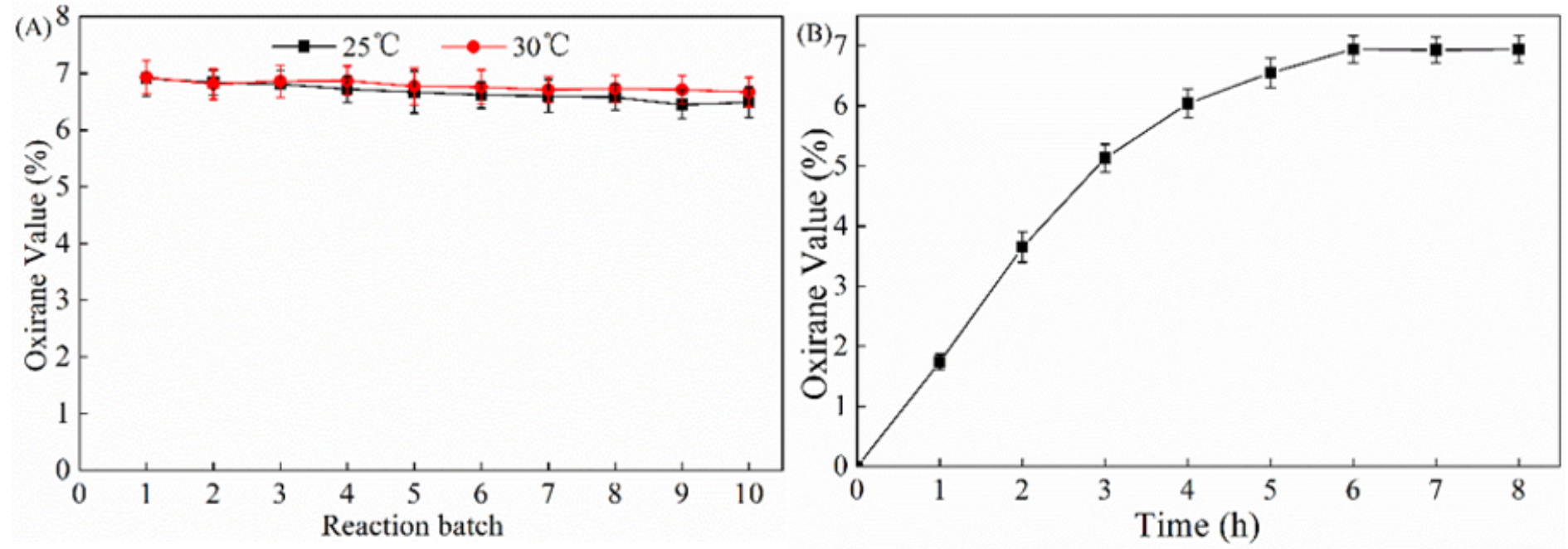

Figure 2

Reaction batch and reaction scale on the epoxidation reaction

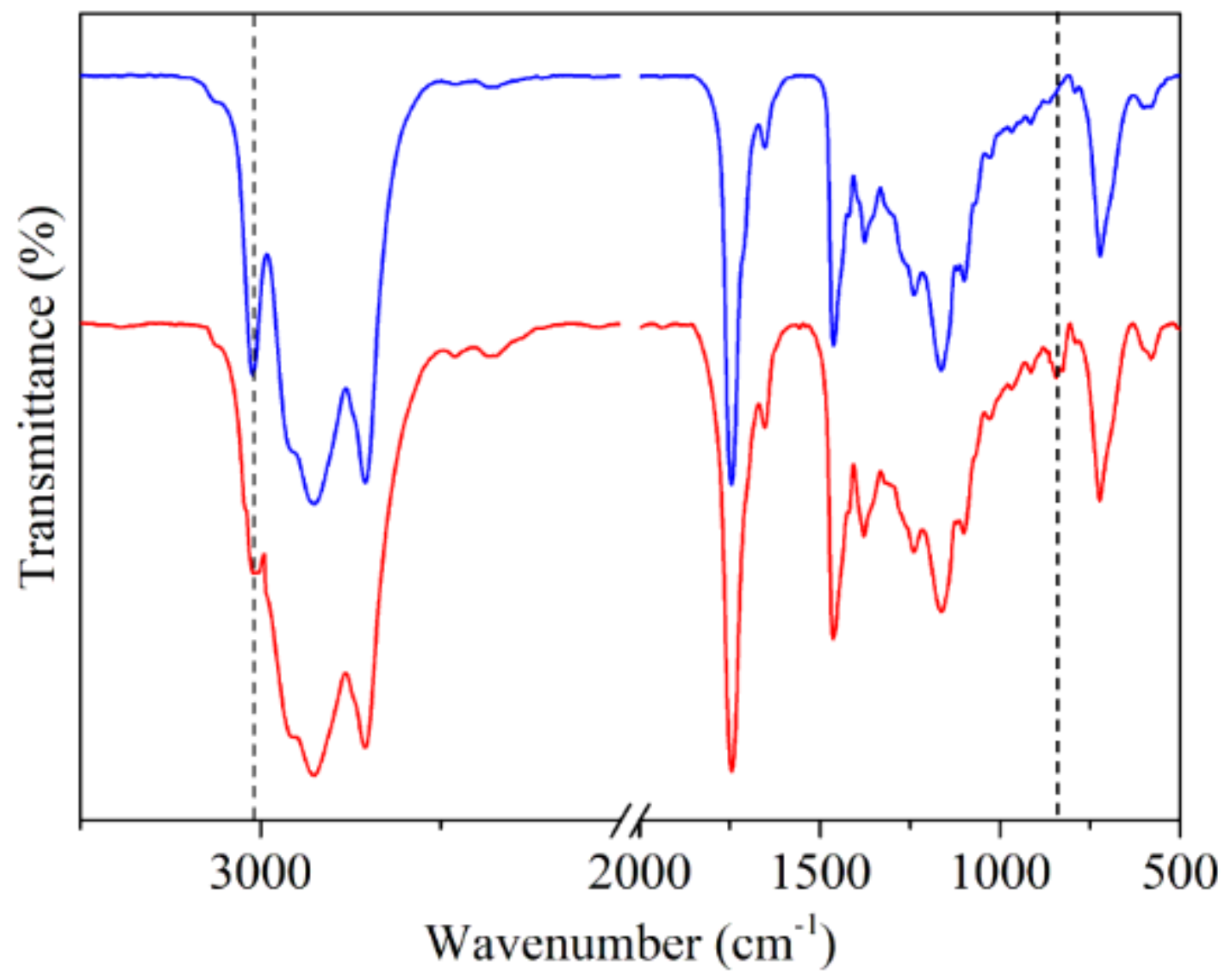

Figure 3

FTIR spectra of SPO before epoxidation (blue) after epoxidation (red) 


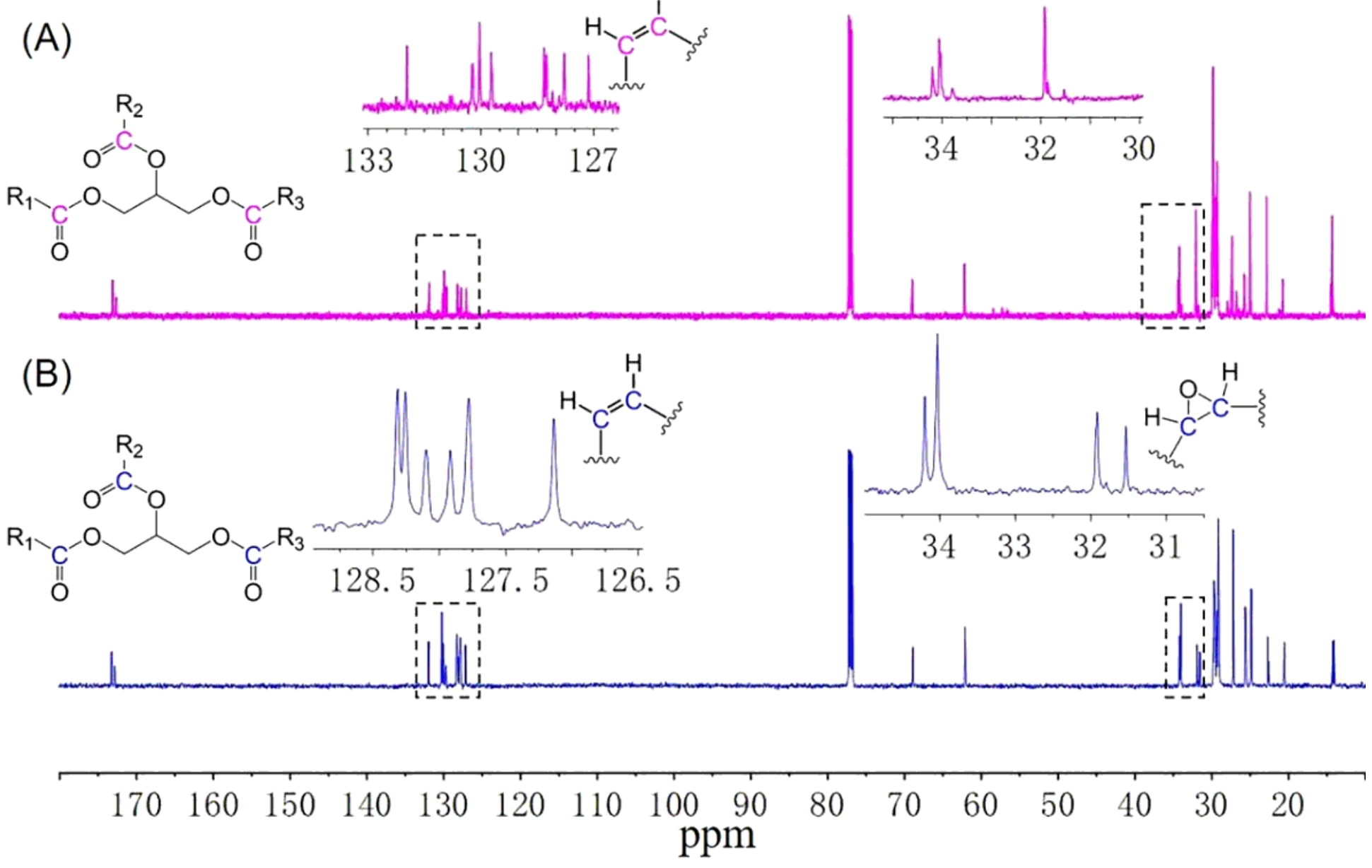

Figure 4

13C NMR spectra of SPO (A) before epoxidation (B) after epoxidation

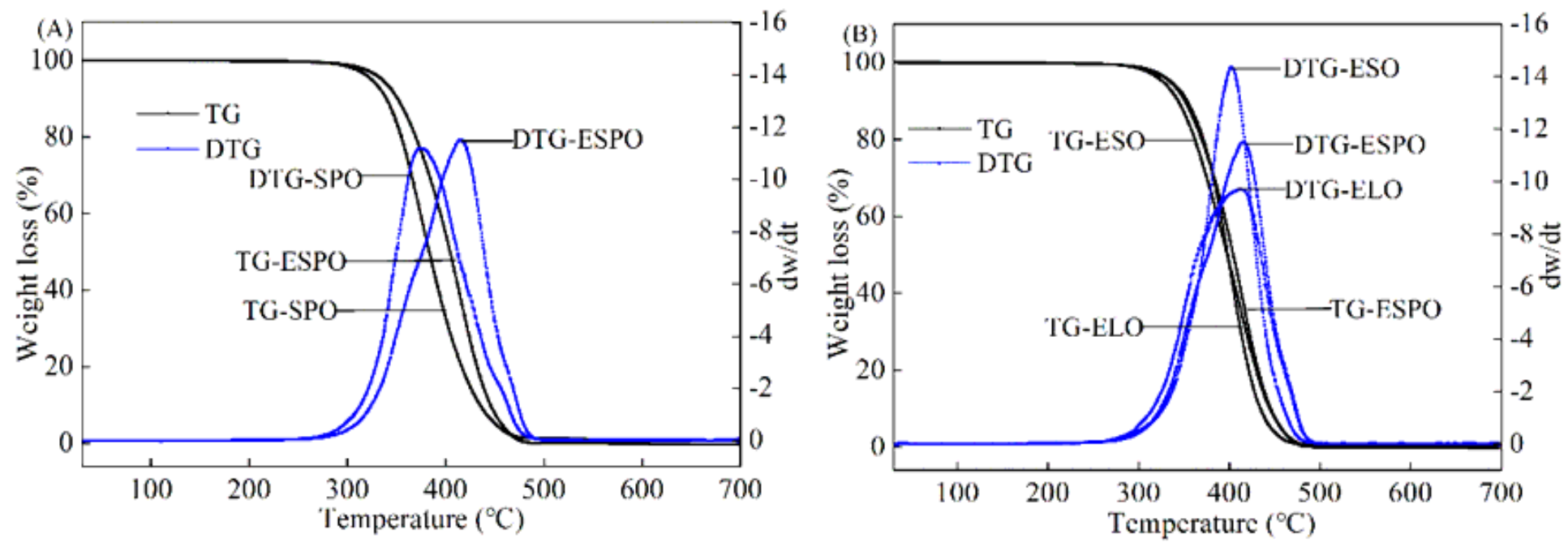

Figure 5

TGA thermographs of the SPO, ESPO, ESO and ELO 


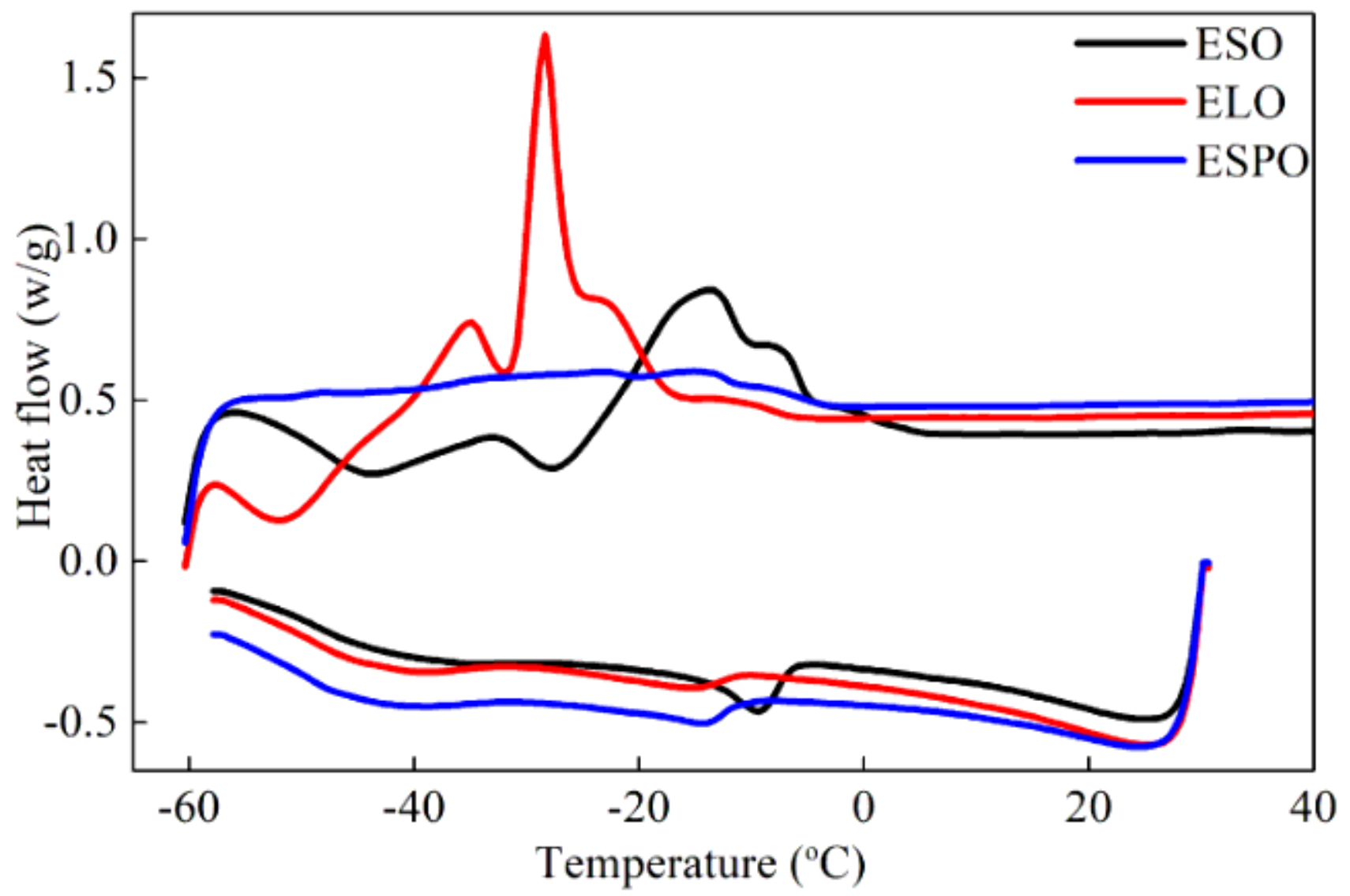

Figure 6

The heat flow analysis of epoxidized oils, the curing agent by DSC
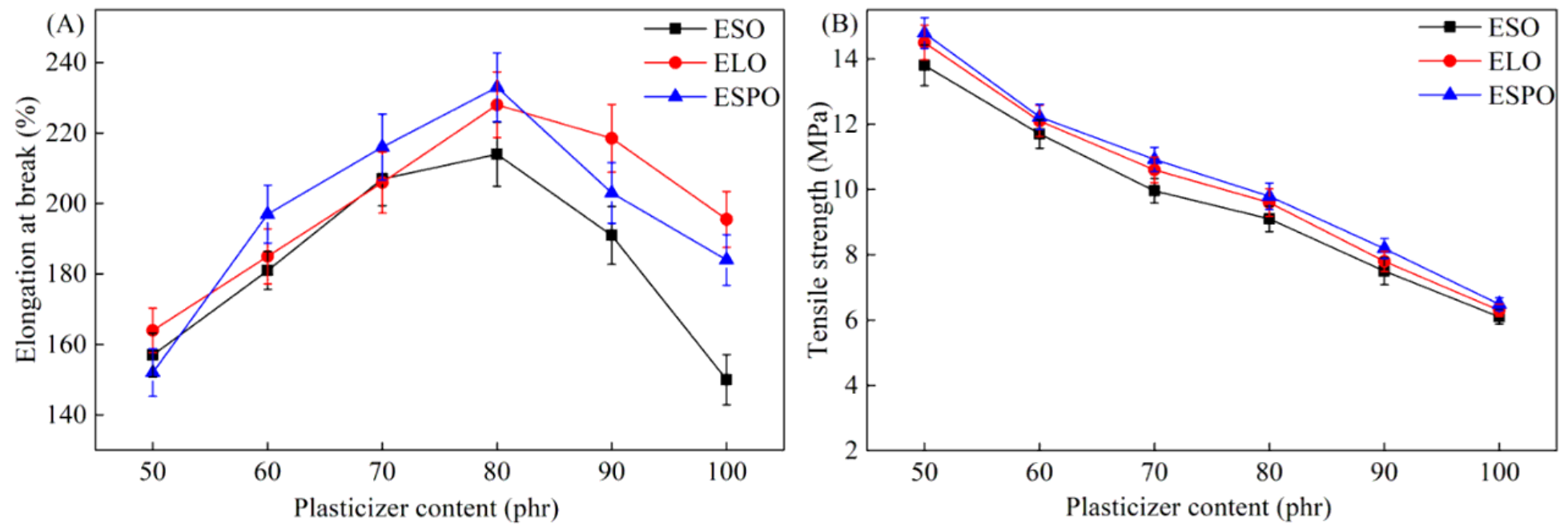

Figure 7

Effects of plasticizer content on mechanical properties 